\title{
The Role of Multimodal Communication in Language Learning: Making Meaning in Conventional Learning Spaces
}

\author{
Robiatus shalihah, universitas negeri surabaya \\ Rusijono, universitas negeri surabaya \\ Andi mariono, universitas negeri surabaya
}

\begin{abstract}
There is space in conventional learning on language learning that must be filled with various ways or methods of delivering information, so it can be delivered to students. The space can be filled out by referring to the principle of multimodal communication by Kress and Van Leeuwen (1996) on how people communicate using different modes at the same time. This paper does not present the results of an analysis of a product design using semiotic mode with multimodality analysis as a procedure of analysis, but it is a theoretical study by linking the principles of multimodal communication with learning theory so that it can be applied in language learning. Therefore, this paper is intended for the purpose of how the delivery of a message by using more than one semiotic modes in language learning in order to make the learning of a conventional nature becomes more meaningful. The use of verbal communication, images, and video as a multimodal communication product in this case has its own role in facilitating language learning. Space in conventional learning methods on language learning can be filled by combining verbal communication, images, and video in the learning process. It will be able to make learning more interesting.
\end{abstract}

Keywords: Conventional learning; Language learning; Multimodal communication

\section{Introduction}

Currently most of the languange learning still apply the old learning patterns of teachercentered learning. Implementation of learning is often dominated by teachers in delivering material and rarely involves student activities. Teacher-centered learning can be regarded as a conventional or traditional learning model. The student learning experience becomes meaningless because it does not engage in discussions, deployment exercises, and explorations. Learning activities also become unattractive because the way teachers communicate to students is monotonous. Language learning should emphasize more on a range of student activities in interacting with other students. Therefore, the conventional learning provides space in language learning. The space should be filled with a various of ways or methods of communication so that the information conveyed can be well received by the students.

The ability of teachers in communicating becomes important in teaching and learning activities. This is because the role of the teacher as a facilitator in realizing effective learning requires a way of communicating acceptable to students. In addition, teachers as desaigner are also expected to design language learning to be more effective and efficient. These needs can be used as one of the problem solving to overcome the existence of space in conventional learning. One way for more effective communication learning then can refer to the theory of multimodal communication.

Multimodal refers to a person's way of communicating by using more than one different way at the same time (Kress \& Van Leeuwen, 1996). Multimodal communication applications in learning can be a teaching technique that combines several modes such as combining the use of images, audio-visual, and text in learning. Merging several different modes of course must consider the competences to be achieved. This is intended to minimize the possibility of error learning method.

Based on the above explanation, this article will explain about the application of multimodal communication in language learning by referring to the theory of multimodal communication and conventional learning principles. 


\section{Literature review}

\subsection{Multimodal communication}

Communication needed in learning is a form of interpersonal communication. Interpersonal communication allows interaction between teachers and students, as well as students with other students. The definition of communication by experts is very diverse, but when observed the diversity has the same purpose. According to Sutikno (2009), communication is a process of delivering information or messages from one party to another happening to influence each other between them.

Interpersonal communication in conventional learning is currently dominated in communication between teachers and students. Sinar (2012: 131) argues that there are three important elements that take part in interpersonal communication, namely: verbal language (spoken and written language), and non-verbal language including gestures, body language, and other. Therefore, the interpersonal communication in learning requires a variety of verbal and non verbal elements that can be used to convey information. This is similar to the concept of multimodal communication.

Iedema (2003) argues that Multimodality can be regarded as a technical term that aims to show that the meaning we make so far utilizes a variety of semiotic. While Chen (2010) interprets multimodality as understanding how the source of verbal and visual semiotics can be used to realize the type and level of dialogic engangement (italics of the authors) in a textbook.

Based on the above explanation, multimodal communication in this case refers to the understanding of all forms of signs (semiotic) on the interactions that occur in a communication that can include, voice, body gestures, body language, text, images, video, and so forth . This understanding is in accordance with the concurrent opinion of Kress and Van Leeuwen (1996), which says that multimodal is a person's way when communicating by using a variety of semiotic modes or media.

Semiotics deals with everything that can be regarded as a sign. So the semiotic modes in this case refer not only to the signs in daily conversation, but also to everything that refers to other forms such as words, images, sounds, gestures, and objects. Language learning often involves the existence of semiotic modes. The most commonly encountered semiotic mode is image-based language learning. For example, images in foreign language learning can be used as a signpost of meaning. It aims to make for students easier to understand the meaning through pictures. Therefore, learning language with semiotics as a sign and ways in multimodality communication is needed. Next sub-title will explain how the application of multimodal communication in language learning in order to fill the space in conventional learning.

\subsection{Conventional learning method}

Language learning includes four basic competencies: listening, reading, writing, and speaking. These four competencies must be achieved by students in order to improve their ability. Learning the language requires regular and controlled exercises to familiarize students in using a language. This is in line with the statement by Tarigan (2009: 50) saying that language learning requires an approach that emphasizes both cascading and controlled exercises.

There are various ways or methods in teaching the language. One of the most common methods is with conventional learning method as in general. In learning by conventional method, the students listen more to the teacher explanation in front of the class and carry out the task if the teacher gives the exercise questions to learners. Some methods commonly used in conventional learning include lecture method, question and answer method, discussion method, and assignment method.

The most commonly used conventional teaching methods is the lecture method. According to Djamarah (2010):

Conventional learning method is a traditional learning method or also called lecture method, because this method has always been used as a means of oral communication between teachers and students in learning process. In foreign language learning the 
conventional method is characterized by a lecture accompanied by explanations as well as the division of tasks and exercises.

\section{Discussion}

Examining the relation of procedures of conventional learning methods by looking at the objectives of language learning, conventional learning methods are less effective. This is because the competence of language to be achieved, especially in reading, writing, and speaking can not be pursued by conventional learning methods that emphasize the activities of material delivery by teachers. Therefore, the step in making conventional learning becomes more appropriate by applying the principles of multimodal communication.

Multimodal communication applications in language learning can be the use of verbal language (voice and text), video, and images. The use of multimodal communication products can make learning activities more interesting. This is in accordance with the mandate in the national standard of education which says that learning should be interesting, interactive, inspiring, fun, challenging, the students' motivation to be active. The use of multimodal communication will lead to interesting learning because it is not monotonous. Multimodal communication in this case indicates the use of learning media in communication between teachers with students. Teachers can communicate verbally by delivering material directly and with the help of instructional media.

The use of verbal language (oral and written) is the most commonly used in conventional learning on foreign language learning. Oral language can be used by teachers in conveying learning objectives and steps. Meanwhile, when delivering a material it would be better to combine it using the image as a tool in giving explanations to the students. The existence of media images by Istriwati (2013) will certainly stimulate students' thinking ability. First, students are interested in the media. Furthermore, students will be interested in the contents of the media used. This sense of interest will encourage students' thinking skills. The use of images as a medium to convey information can be used as a method of training by students in class or students in groups. One way is by presenting pieces of pictures in a group that must be arranged in the form of narrative sentences. This way can lead to student interest and activeness in learning. Learning by involving student activeness directly can improve students' ability.

The relationship between the image as a medium of communication with instructional media mentioned by Suleiman (1988: 28) that,

In relation to the instructional media, it is also disclosed that the images that can be used are images that relate to the lessons or problems encountered. In this case the teacher should be able to direct the interest of students who are looking at the image, which is getting answers to the questions that arise in his mind. The image should be able to stimulate the participant's participation so that he likes to talk about the pictures he sees.

For example in foreign language learning, students should be able to know the use of language that is learned in real and factual. So from, the presence of video can answer the needs of students in knowing the language closer to real conditions. Video media is included in the category of multimedia because it contains many means to convey messages in learning include, text, images, and sound. In multimodal communication, video is one form of product of multimodal communication.

Video is perfect for learning because it has several advantages. According to Nugent (in Smaldino et al, 2008: 310) said that:

The video is perfect for a variety of learning, such as class, small group, even for one student. What's more, students today can not be separated from technological advances. So the video is able to provide more convenience for teachers in directing learning directly to the needs of students.

The above explanation requires that language learning with conventional learning methods can be balanced by combining verbal communication, video, and images. This is in accordance with the principle of multimodal communication that requires a communication in 
various ways or methods of communication at the same time. Ways or methods of communication in language learning may refer to the use of instructional media, while ways or methods in multimodal communication can be products of images, videos, movies, advertisements, and others. Thus, the product of this multimodal communication can be used as a medium of learning, especially on conventional learning.

\section{Conclussion}

Images and videos are some examples of products of multimodal communication. The connection in learning is that images and videos are a form of learning media. It means that communication in true learning is an integrated entity. Learning is always a communication, but the communication that occurs in conventional learning on language materials is often limited to verbal communication in the form of oral and written only. Limitations of this communication is a space in language learning because it is not in accordance with competence

Based on the above explanation, it can be deduced that the principle of multimodal communication can be applied in a conventional learning space in order to become more meaningful. Conventional learning not only emphasizes the activity of oral communication between teachers and students, but also can be modified using some means of communication such as using pictures and video. This way can lead to meaningful learning because of the interesting and interactive learning conditions.

\section{References}

Chen, Y. 2010. Exploring Dialogic Engagement with Readers in Multimodal. EFL Textbooks in China. Visual Communication.

Djamarah, S. B. 2010. Strategi belajar mengajar. Jakarta: PT Rineka Cipta.

Iedema, R. 2003. Multimodality, resemiotization: Extending the analysis of siscourse as multisemiotic Practice. Visual Comunication, 1-30.

Istriwati, E. 2013. Peran Media Gambar dalam Pembelajaran Bahasa Indonesia Berbasis Teks di Sekolah Dasar (journal article). Universitas Muhammadiyah Surakarta: Balai bahasa provinsi jawa tengah. http://hdl.handle.net/11617/3359

Kress, G. dan van Leeuwen, T. 1996. Front Pages: (The Critical) Analysis of Newspaper Layaout. In Bell, Allan. and Garret, Peter (Eds), Approaches to Media Discourse. Oxford: Blackwell.

Sinar, T. S. 2012. Teori \& Analisis Wacana Pendekatan Linguistik Sistemik Fungsional. Medan: Mitra.

Smaldino, E. S. et al., 2008. Instructional Technology and Media for Learning $\left(9^{\text {th }}\right.$ ed). Upper Saddle River, New Jersey Colombus, Ohio.

Suleiman, A. H. 1988. Media Audio Visualuntuk Pengajaran, Penerangan, dan Penyulihan. Jakarta: Gramedia.

Sutikno, M. S. 2009. Belajar dan Pembelajaran Efektif. Bandung: Prospect

Tarigan, H. G. 2009. Pengajaran Kompetensi Bahasa. Bandung: Angkasa. 